\title{
Participatory Action Research: a case study on the school democratisation process
}

\author{
Auxiliadora Sales, Odet Moliner, Joan Traver \\ Universitat Jaume I, Castellón, Spain
}

\begin{abstract}
Participatory Action Research (PAR) in the educational context is a coherent methodology to accompany processes of school democratisation focusing on the key elements of collaborative culture, a sense of belonging and social transformation from an inclusive and intercultural approach. The present case study of a rural school in the Valencian Community (Spain) takes an ethnographic approach to analyse how PAR strategies and processes facilitate the democratisation process and the educational community's perceptions of the transformations in the school culture. Results show an improvement in participation strategies and a more distributed leadership, but they also reveal some resistance to delegating responsibilities and difficulties in empowering children's voices. The conclusions highlight the need to institutionalise cultural change by understanding participation as a fundamental strategy with which to build a more inclusive and intercultural school and society.
\end{abstract}

Keywords: participatory research; action research; diversity; inclusion; democracy.

\section{Introduction}

The change in the concept and problematisation of diversity specifically concerns the institution of the school as a crossroads of cultures and a privileged space for inclusion and interculturality. Inclusion refers to the right of subjects to actively participate in the democratic life of society, while interculturality is concerned with empowering and enriching relationships among people in a plural world. Both principles are grounded in the recognition that schools are heterogeneous in their composition, and guarantee the 
right to equality and the right to be different without exclusion from the resources and strategies of participation and learning (Ainscow 2016; Coulby 2011). The inclusive and intercultural educational approach implies a conception of education and culture as an open, dialogical and dynamic process (Holliday 1999), and therefore calls for an educational model that understands diversity as a value and a norm rather than a deficit or a problem; a model designed to combat racism and exclusion through dialogue, cooperation and democratic participation (Armstrong, Armstrong, and Barton, 2000; Sales, Traver, and García 2011).

\section{The inclusive, intercultural school as a democratic model}

This approach assumes that the school, as a social institution, should be a living space where active democracy facilitates full participation and the construction of collective knowledge based on its social context (Kincheloe and Steinberg 1997; Susinos and Rodríguez-Hoyos 2011). As a democratic strategy, full participation calls for a mechanism through which members of the community take decisions by listening to all voices and accepting the commitment to play an active role in a process of social change towards equity, inclusion and social justice (Muijs, Ainscow, Chapman and West 2011).

The key factors of this democratic school are:

- A shared cultural project of common values and objectives that gives meaning and cohesion to the educational community (Ainscow et al. 2012).

- Spaces and times for citizen participation: establishing routine moments and places for participation in school life, creating opportunities for learning and dialogue (Fullan, Quinn, and McEachen 2018; Sales, Traver, and García 2011). 
- A network of support and cooperation to increase schools' culture and capacity to deal with diversity in an inclusive and a sustainable way (Echeita et al. 2013; Hargreaves and Fink 2006).

- Commitment to social change (Bourn 2015).

\section{Researching school democratisation processes through PAR}

The transformation towards an inclusive and intercultural school is therefore a democratic process that requires a research approach that is coherent with this educational model based on the intersectionality of inequalities and the fight against exclusion and racism. PAR assumes an understanding of the school as a privileged learning space for all those involved in its educational project, and at the same time, opens up avenues to higher levels of awareness (Lozano, Traver, and Sales 2016). PAR is a research method and community action that seeks to transform and improve the social reality, in this case the educational reality. It consists of a systematic process of reflection and action undertaken by a specific community to reach a deeper understanding of its problems and attempt to solve them by involving the community throughout the whole process, and guiding change from within, not controlling it from the outside (Ander-Egg 2012; Reason and Bradbury 2008).

The aim of this study is to describe a PAR experience in a school context and how its implementation impacted learning experiences in the school, how all constituents engaged in the school democratisation process, and how this democratisation plays a role in on-going transformation within the school.

As a model for professional development, PAR resources can be used to deconstruct the exclusivity of professional identity and empower teachers and the rest of 
the educational community when there is learning unity in the school (Elliott 1991). The external researchers' role is one of 'critical friends' who encourage and accompany the teachers in their reflection and action, and must acknowledge the autonomy and responsibility of the teaching staff to manage their own learning processes. Indeed, one of the aims of PAR is to generate greater equality in the researcher-participant relationship. The researchers' role is to draw out their assumptions, motives and values, and provide the resources for teacher and community empowerment throughout the process. These resources include offering technical expertise, training local people in research skills, taking an active pedagogical role, and motivating community participants to critically analyse their reality (Dickson and Green 2001, 246-247).

The literature demonstrates that, firstly, action research is a channel for developing the capacity of school communities to expose and challenge deeply entrenched deficit views of diversity, which define certain types of students as 'lacking something' (Ainscow 2005; Coulby 2011). Secondly, it is collaborative, participatory, democratic, and designed to develop critical and transformative community learning (Armstrong and Moore 2004; Kemmis, McTaggart, and Nixon 2014).

As an inquiry process, PAR is therefore based on principles of collaborative culture and democratic participation, a sense of belonging to the educational community and social transformation.

Collaborative culture and democratic participation: Brydon-Miller and Maguire $(2009,83)$ define PAR 'as a framework to enable teacher and/or school-based practitioner inquiry to become more participatory, collaborative, and democratizing in ways that meaningfully engage students, families, and other educators, from problem identification to making project results and implications public'. 
PAR principles are thus based on the notion of research as a form of political engagement that encourages educators to work with their students and community partners to explore the social, economic, and political contexts of schooling (DarlingHammond 2006; Sleeter 2007).

Building a sense of belonging to the educational community: Kemmis (2006) takes a social-communitarian approach to explore integrative projects across the schoolcommunity boundary that foster social action by students in the interests of community development. In this line, Baum, MacDougall and Smith argue that 'the reflective process is directly linked to action, influenced by understanding of history, culture, and local context and embedded in social relationships' $(2006,854)$. Through critical action research projects, the education community can jointly explore issues that call for shared deliberation and decision making.

These PAR projects connect the themes and issues of interest both inside and outside the school and encourage intercultural communication about the variety of ways practices are understood, from a range of standpoints and cultural perspectives. The sense of belonging to the educational community requires an open communicative space for dialogue, and the acceptance that intersubjective agreement, mutual understanding and mutual consensus are always situated and provisional (Kemmis 2006).

\section{Social transformation and changes in school culture: PAR can generate} collective action in public spheres to transform practice and community settings (Kemmis, McTaggart, and Nixon 2014). On one hand, it works to address the causes of inequality, and on the other, it focuses on finding solutions to community issues and questions (Williams and Brydon-Miller 2004). Brydon-Miller and Maguire (2009, 82) identify three kinds of potential change that PAR can promote: the development of 
critical consciousness and agency of co-researchers, the improvement of participants' lives, and the transformation of basic social structures and relationships.

Drawing on this previous work, the aim of our research is to understand how the PAR undertaken in a rural school in the Valencian Community (Spain) has favoured a process of democratisation in transforming the school towards an inclusive and intercultural approach. This experience enabled us to reflect on PAR as a research methodology that not only aims to generate new scientific knowledge, but also benefits the participants and the environment in which the study is carried out.

The paper considers the potential of PAR as a coherent research methodology to facilitate the democratisation process in an educational context through collaboration, sense of belonging and social transformation (Table 1). The study finds that PAR helps to improve participation and distributed leadership.

Table 1. Relationship between inclusive intercultural school and PAR.

\section{Case study}

\section{Research context}

This research is framed in the context of a 'centro rural agrupado' (CRA), a rural primary school serving two small populations on different sites (two villages with 632 and 1,083 inhabitants, respectively). For administrative purposes, however, it is considered as a single school. Since its foundation the school has aimed to go beyond its purely administrative definition and construct a new way of seeing itself as a community with shared values, one that learns and works cooperatively and collaboratively on its path to becoming an inclusive intercultural school, despite being based on separate sites. 
The school has 150 pupils and 15 teachers, practically all of whom are permanent staff members. The families come from the locality and neighbouring villages, and include a small percentage of immigrant families (three percent come from Morocco and Latin American). The school has a support team for students with special educational needs (speech therapist, counsellor, SEN teacher) who serve students with temporary or permanent learning difficulties. Two years ago, this team began to review its practices in order to shift its focus from a therapeutic to a more inclusive model.

Both villages have several associations that are heavily involved in school life. The school has gained a reputation through its five-year project to build an inclusive intercultural school, and as a result has attracted families from other surrounding towns who are interested in its pedagogical approach. The project, led by the management team and teachers, focuses on methodological innovation (cooperative learning, projectbased learning, peer tutoring and learning service) and on creating democratic participation structures (mixed working committees, a coordinating committee, student and community assemblies, open days) that have become established as collective decision-making bodies. The school's motto and mission statement, 'We are more than a school: we are a democratic, participative and inclusive community', has been widely disseminated through social networks and the school's website. As a result it has become a model institution visited by other professionals in the region.

\section{Improvement process}

In this innovative context our research team, as critical friends, facilitated the implementation of PAR spirals in an improvement process for school democratisation. We used participatory social diagnosis (PSD) techniques (Castro et al. 2007) to ensure the participation of the whole community in the different PAR stages. These techniques 
facilitate increased critical awareness in the community (Aguirre et al. 2017) and encourage social transformation processes (Villasante 1998). The techniques used were:

(a) Timeline: a technique that pinpoints key events in the community's history which help identify trends, important events, problems or progress in the life of the school community (Alberich et al. 2009).

(b) Social Mapping: a graphic representation of the groups and organisations in the territory and the possible relationships established between them (Alberich 2008).

(c) My ideal school: participants express their wishes for their ideal school through a painting, a panel or other creative formats in order to share a dream image to build together (Escudero 2004).

(d) The Mirror technique: based on feedback of the picture created from the data obtained in the previous activities, using creative forms adapted to the participants such as posters, murals, photo exhibitions or videos. Participants come together to critically analyse the data and make decisions about the next step in the process (Aguirre, Escobedo, and Sales, 2014; Deltoro 2004).

We followed the stages described below to develop the improvement proposal through PAR spirals (Ander-Egg 2012):

(1) First contact and shared negotiation of demand. In this stage we made initial contact to explore the demand. Our aim at this point was to identify and define the problem and the project's objectives together. The first meetings with the management team and the teachers focused the aim on improving community participation in the school, so as to make it more democratic and ensure that everybody could feel part of the project to build an inclusive and intercultural school. A subsequent 
assembly with families and students concluded that people learn to participate by participating, and as a result they were motivated to be part of it.

(2) Diagnosis and shared analysis. Having defined the initial demand, in the second stage we began a more detailed and deeper analysis of the school's history and reality. An open day was organised where students, teachers, families and local authorities gathered to jointly explore their problems, needs and potential, and to find out how members of the school feel about and describe the situation in the school. The PSD methods used were the 'My ideal school' technique to start a participatory process to create a picture of the vision, goals and dreams for transforming and improving the school. The timeline strategy was also used to build a shared awareness of the school's history, its organisation and participation in it, as well as its relationships with the local community. The social mapping activity created a map of local sites that the community used for recreation and enjoyment and that could be linked with school activities. This stage concluded with a session to share and critically analyse the information compiled in the open day through the mirror technique. Finally, the mirror strategy session was developed to feed back and discuss all the information in a mixed working group (students, teachers, families and researchers).

(3) Planning the action. The needs detected and analysed in the previous stages formed the basis to plan the action. To this end, we first jointly drew up proposals for action and prioritised them. The nominal group technique was used to encourage contributions from all members of the community, who first wrote down the proposals and then chose the best idea they felt should be taken forward. The ideas were presented and the suggestions were then discussed and prioritised by the whole group. The decision was taken to focus the analysis and improvement process on two practices: 
(a) Didactic classroom strategies (peer tutoring, learning corners, Aronson's jigsaw, and Kagan's cooperative structures). Four teachers offered to open up their classes for observation and interviews in order to analyse the cooperative and inclusive learning strategies applied in them. Family members and researchers observed the classes, and interviews were carried out with teachers, students and families.

Pre-primary: Showdown (Kagan cooperative learning structure) for learning mathematics. In groups, students first learn to discuss the right answer and then write it down without talking.

2nd grade primary: Learning corners. Each classroom corner has a different didactic purpose and materials for playing and learning autonomously. Children choose which corner they prefer and work in small groups.

4th grade primary: Peer tutoring to improve reading. In pairs, one student is the tutor and the other the tutee; they work together following a structured guideline to prepare and assess the reading text.

6th grade primary: Aronson's jigsaw for learning mathematics. Students work in heterogeneous groups (the jigsaw group). The topic is divided into parts and each team member is an 'expert' in one of them. The experts first work together and then go back to their jigsaw group to share what they have learned with the other group members.

(b) A school management practice (Coordinating Committee): the School Council is a formal management body with student, family, teacher and local authority representation. Because of its heavily bureaucratic function and regulations, the management team decided to expand it to incorporate all members of the mixed 
working committees (library, events, complementary activities, etc.). These committees inform and take decisions on day-to-day school business.

(4) Putting the action into practice. Ander-Egg (2012) recommends that operational control of interventions in this implementation stage should take place through action-reflection-action. The implementation process was documented using various information-gathering tools (participant observation, research team's field diaries and interviews) in order to provide an account of each action undertaken; the voices of all participating groups were considered in the process. All the data gathered about the didactic classroom strategies and the Coordinating Committee were organised and then triangulated, analysed and discussed by the community in the following stage.

(5). Action evaluation and monitoring. The improvement loop was completed in this stage by validating the information through triangulation (tools and sources) and evaluating the effectiveness of the actions carried out, for which a review of the work undertaken was a useful exercise. Having organised this information, it was fed back to the educational community for critical analysis by all the groups involved, once again using the mirror technique. This evaluation was carried out on two separate occasions. We first ensured that each sector of the educational community was able to analyse the information independently and give their critical judgement, particularly in the case of the groups whose voice is frequently silent in such processes (students and families). On the second occasion, the critical reports from each sector were presented in a large assembly, where they were compared and the whole community was able to take stock of the outcomes.

\section{Research methodology}


The project was framed as an intrinsic case study (Stake 1998) of the school's educational improvement process based on PAR spirals. We took a qualitative, ethnographic approach to analyse the data on the situation. As a case study, we were motivated by an interest to understand a unique reality and the importance of the research context in our pursuit of meanings that would help us to describe and understand the case. As a qualitative ethnography, the research was a descriptive study that applied qualitative instruments to obtain thick descriptions.

In defining the case, the research problem arose when the infant and primary school began an improvement process that, following the PAR spirals, sought greater democratisation and improved educational practices through an inclusive and intercultural approach.

The study aimed to analyse the democratisation process in the school in order to discover how the PAR process unfolded and what changes occurred in the school culture as perceived by those involved. The following research questions were formulated in relation to this objective:

(1) How does a democratisation process using PAR develop in this school?

(2) What changes are taking place in the school culture following this democratisation process?

The PAR activities were opened up to allow participation by members of the school's educational community (teachers, families and students), other community agents, the education department and local councils. A total of 76 key informants actively participated in at least one stage of the data generation process in this study, namely, 25 family members, 14 teachers and 25 students and 12 members of the 
research team. Student participation was guaranteed with the collaboration of the teaching staff, who facilitated accessibility and helped the students understand the dynamics of the process.

The data were gathered using the qualitative ethnographic methods of participant observation, interviews and group discussions, audiovisual recordings, documentary analysis and the research team's field diaries.

Table 2. Data generation and codification of methods and participants.

The questions arising from the interviews and focus groups fell into three broad areas: a) items about the participation of different sectors in the educational community in the school improvement process; b) perceptions of the leadership of these processes; and c) perceptions of their experience and involvement in the process and the transformations.

The data gathered were transcribed and classified by the research team and then fed back to the educational community for participative analysis. The Atlas-TI program was used to analyse the data by themes. We followed the systematic classification process of coding and identifying themes or patterns combining deductive (previous categories) and inductive (open coding, emerging categories) categorisation (Elo and Kyngäs 2008). This analytical process enabled us to identify the most relevant themes by comparing data according to their saturation and potential to respond to the research questions. The procedure to validate these categories followed the qualitative research credibility criteria of using persistent observation, checking with participants and triangulation (Cisterna 2005; Guba and Lincoln 1985; Rodríguez, Lorenzo, and Herrera 2005). The data sources (researchers, teachers, family members and students) and 
research tools (interviews, observations, documentary analysis) were used in the triangulation process.

Finally, it should be noted that the research team's position was coherent with the principles of PAR. According to Le Grange $(2009,4)$, 'The participatory character refers to relations of cooperation, mutuality and reciprocity that exist between the researcher(s) and other participants. Participants are involved directly and as equitably as possible in all dimensions of the research process'. In line with this PAR position, a process of collaborative inquiry took place during each stage of the information gathering and analysis, in which the tools and content to be used were negotiated, the transcripts were returned to the informants for their supervision, and the analysis and interpretation of the information was shared using PSD strategies such as the mirror technique. Ethical standards were upheld by providing information and then negotiating the aims and characteristics of the study with the educational community to ensure they felt a sense of ownership of the project. All participants were informed of the aim and characteristics of the research, the research rapport was negotiated with them, the conditions were agreed and their informed consent was obtained.

\section{Findings}

Following a deductive categorisation (democratic participation, social transformation, sense of belonging and collaborative culture), an emerging category (shared leadership) was found.

\section{How does a democratisation process using PAR develop in this school?}

To answer this first question the data were analysed based on the categories presented in Table 3, categories and number of citations in Research Question 1. 
The informants considered that the PAR process involved the participation of students, family members, teachers, the research team and representatives of local associations and institutions.

They referred to the open day as one of the democratic participation strategies for raising awareness and disseminating the school improvement project. In preparation for this day, the management team convened a meeting to plan activities and themes with representatives of the teaching staff and the family association, together with student delegates and the research team. Tasks and responsibilities were divided among small mixed working committees. A call was put out to the neighbourhood, local agents and authorities. The students played a major role by explaining what they learn at school. The climate was one of collaboration and, for the first time, the project was clearly framed as a shared initiative that all the community could feel part of.

At the open day the community were given academic information, an explanation of the hallmarks and principles of the shared school project (democracy, inclusivity and participation) and the curricular practices that would help in its development. In this frame, new teachers and new families were welcomed, extracurricular activities were presented, social diagnosis activities (dreams, mirror, social mapping and timeline strategies) took place, as well as recreational-festive and group cohesion activities (dances, community meals, etc.).

Furthermore, participatory training activities were run for teachers at the beginning of the school year in order to welcome new teachers and ensure that they and other newcomers felt part of the project and took the initiative to join in and own it. 
At the beginning of the school year, in the first staff meeting we give an explanation (of the project and the classroom methodology). Well in this case it was A., who did it the year before and set it up, who explained to everyone how we did it. (PT, TI)

Another strategy referred to as part of the PAR process was the shared analysis of didactic classroom strategies. The mirror technique was used in these assembly meetings, where the research team presented the data gathered through observations and interviews and transferred to a database, and created a shared space in which to analyse and discuss them all together. An important strategy in this process was to formally convene the meeting in order to ensure maximum attendance of participants.

The children will present the practice (which ensures their voices are heard). The family members will then speak, followed by the university researchers and finally the teachers. The sessions will be held in the evening and the headteacher will create an online questionnaire for families to choose the day that best suits them. (MS, FDRT)

Likewise, the careful planning of students' participation in the assemblies guaranteed their visibility and gave them a prominent role in presenting the information to the other agents as well as making proposals for improvement:

Second cycle students [ 8 to 10 -year-olds] explain the activity (reading in pairs) with a PowerPoint presentation, and the third cycle students [10 to 12-year-olds] make proposals for improvement: make reading passages shorter and easier for certain ages; the second reading could be done as a group, not consecutively; and make the classroom less noisy (lower noise levels when all the children are reading in pairs). The teacher asked the families to help the children prepare their reading passages at home. (MS, FDRT) 
The teachers supervised these student interventions and helped them prepare the session. The families also had a space in which to initiate debates on classroom practices and make proposals for improvement.

Two mothers make contributions in the time assigned for the family members. One of them evaluates the activity positively (reading in pairs) but wonders why they have to all read at the same time. Students and teachers reply that it is to improve reading intonation. The other mother proposes changing pairs more frequently, and she is assured that this comment will be taken into account. (MS, FDRT)

Shared analysis of the classroom practices was valued as a participative strategy, although criticisms have to be tolerated:

You go to the next school and they don't look at everything down to the last detail like here, because people can't participate, there's no democracy, the proposals are put in place whether you like it or not. What happens here? We make a proposal and we create the conditions for it to be analysed in depth and... you get nothing but criticism (CC,TI)

The teachers were aware of family diversity and the multiple cultural visions of participation held by local families and newcomers.

\section{The path to shared leadership}

Informants also mentioned participation structures that enable direct participation in decision making. On this point, the community's participatory bodies, such as the School Council (governing body comprising elected representatives from the teaching staff, families and teachers) and the Coordinating Committee (voluntary members from the mixed working committees) were created to encourage everyone to participate democratically, although in many cases the families and associations preferred to speak directly to the management team: 
Normally people come and say, "Hey, could you ask this?" They ask you directly and if you resolve the issue then that's that. If you can't, then you pass it on. But in any case, now the Coordinating Committee and the School Council are open to everybody. Anyone who wants to can attend (CC, FI)

The informants considered that the school's management team, with the support of the teachers, led the process and the improvement project. They mobilised the educational community to guarantee their participation in analysing the classroom practices, and when convening the meetings the place and the time were carefully considered so that all agents would be able to attend and participate.

Yes, we do it with a computer program so they can vote and choose their options from home. They can also vote using their mobile phones. $(\mathrm{CC}, \mathrm{O}, \mathrm{T})$

There was the feeling that things could be done with everyone's involvement and that the families could express their ideas on how to find solutions in collaboration with other agents:

I have a couple of ideas, that would be to bring the parents' associations together with the town councils and see how far we can go to offer a zero cost, so on Fridays the children can stay at school until 5 o'clock. (CC, O, F)

The families positively valued the opportunity the headteacher offered them to make decisions:

For me, one really important thing is that the headteacher gives us the vote, because he is the one who has the last word here and he gives all of us the chance to decide and vote, and I want everyone to bear this in mind. $(\mathrm{CC}, \mathrm{O}, \mathrm{F})$ 
However, on the question of leadership of the process, some family members considered that the management team organised the Coordinating Committee from within, responsibilities were not delegated and therefore self-management was not encouraged:

Is responsibility for the Coordinating Committee's tasks rotated? No, it's the management team, they are the ones that organise it (CC, FI)

They valued the opportunity to participate in the school, but were concerned about the lack of times to do so. Schedules were a limiting factor: despite arranging the meetings so that as many people as possible could attend, work commitments prevented some from doing so.

Committees were also created to organise events, made up of teachers and parents, although students did not take part.

We set up a committee for last year's end of course festival. It was a committee of parents and teachers where anybody who wanted to could participate without any problem. It worked really well. (CC, TI)

The students also positively valued their families' involvement in the school and their own opportunity to give their opinions; however, they considered that in the large community assemblies it was sometimes more difficult for them to participate and although they were present, they were in a minority.

It's like, there are a lot of people and we can't all participate $[. .$.$] There aren't many of$ us students, they don't feel encouraged to come (CC, SI) 
Similarly, although they did sit on the Coordinating Committee, they felt at a disadvantage because they did not understand the language used, which hindered them from taking part in the discussion:

I don't know... it was 'strange' because everybody was saying things and I didn't know what was going on... I thought... are they talking double-dutch or what? (CC,SI)

However, they felt very positive about the fact that "their" school and "their" project were taken into account; that is, they felt part of the school project, as expressed below:

...we, although we might be the youngest, we can change things, because we are in the project and we are in the school. So we can say what we think and give our opinions. $(\mathrm{CC}, \mathrm{SI})$

Furthermore, collaborative decision making through the Coordinating Committee was seen as an opportunity to learn how to live democratically.

Yes, I think it is positive because we are making people participate actively in fundamental issues for the school. The most important questions are dealt with in the Coordinating Committee with the support of the School Council. I view this as very positive, although all of us need to learn how to function more democratically. (CC,TI)

This need to learn how dialogue can be the main strategy for making collaborative decisions is related to a more sensitive approach involving different ways of communicating and understanding school culture from the teachers' and families' diverse cultural perspectives.

\section{What changes are taking place in the school culture following this democratisation} process? 
To answer this second research question we analysed the data categorised in the codes presented in Table 4. The number of citations is much lower than those classified in response to the first question, suggesting that the educational community has a lower perception of the transformation processes.

Table 4. Categories and number of citations in Research Question 2

\section{Openness to the community}

We started from the notion that school culture is defined on the basis of the attitudes, values and beliefs that are specified and accepted by the educational community. In this line, the teachers stated that they clearly understood the objectives of the school and the improvement project: to advance towards democracy and participation.

The teachers' favourable attitude to the project was manifested in their availability and openness to the community:

We always say that when someone is unsure about something, instead of talking outside the school, they should come and ask, that we are more than happy to see people. What doesn't seem fair is that sometimes the information we gave here is manipulated and not treated with consideration when we have opened up the school to everybody. Anyone can come here and talk, or attend a Coordinating Committee meeting $[\ldots](\mathrm{CC}, \mathrm{TI})$

Indeed, one of the most significant organisational changes in the school is the creation of the Coordinating Committee, a body that encourages participation. It is defined as a body that any member of the community can attend and participate on a voluntary basis, and is explicitly stated in the School's Educational Project, the most important school document, accepted by the educational community and approved by the School Council. 
The first point is the modifications to the Educational Project, which must be approved by the Council. Modifying or adding agreements we reach in the School Council is open to the whole educational community, so everyone has a voice even if they don't have a vote. But they can come and listen and give their opinions... (CC, O, T)

However, it seems that there is still some resistance to democratic participation:

Often an issue of general interest is raised, but it leads to controversy and in the end we can all come out worse if we don't deal with the issues in the right place. People must realise that they have to participate. Until people's attitudes change and we all actively participate and learn to participate more democratically... It is a process...but I think we'll improve if we start from that basis... (CC, TI)

Not all the families agreed with the project. Some local families saw newcomers as a threat and began to call for a more traditional teaching style.

\section{Learning to make consensual decisions}

Changes were also perceived in the decision-making process, which evolved from simply voting to the pursuit of consensus through dialogue.

Before, everything was done unanimously or by vote. Since it's been opened up to everyone we have always tried to reach an agreement. $(\mathrm{CC}, \mathrm{TI})$

The teachers acknowledged the changes that had taken place over time in the school, which now takes a more participatory approach. The most visible transformation was in the families' engagement. The teachers also recognised that the school had gradually made advances in transparency and in the way information is explained. Everything is part of the learning process. 
We're going through a learning process because before, four or five years ago, when someone said something here, that was her view, there was no debate. We've gone from one extreme to another and that's complicated. Sometimes we make mistakes, sometimes people make mistakes, and people are not always used to participating in more formal places. People have to learn and so do we. (CO, E, M)

The question about what kind of families participate and how teachers and families understand mistakes in participation is related, once more, to the different cultural visions of school change and the political tensions surrounding the project.

\section{The impact on instructional strategies}

The teachers expressed an incipient interest in transferring some of their traditional functions to students through the figure of the 'class monitor', rotating roles in classroom activities, or in evaluation (co-evaluation and self-evaluation), in an attempt to shorten the hierarchical distance in actions with the students:

\footnotetext{
We discussed some pertinent questions: when a student asks the teacher a question, they do not simply respond but return the question to the child to encourage reflection. Also of note is the respectful relationship the teachers have with the students, using an affectionate tone of voice and communicative body language to ensure they are on the same level as their students. (LC, O, RT)
}

Teachers and students indicated how student engagement impacts pedagogy and has the potential to affect the children's learning experiences. Cooperative classroom strategies (peer tutoring, learning corners, Aronson's jigsaw, and Kagan's cooperative structures) encouraged responsibility: 
You have a responsibility because if you did it well, the 'team' already has everything wrong and if you are not 'explaining' the 'team' has to spend more time on understanding the problem $(\mathrm{AJ}, \mathrm{S}, \mathrm{SI})$

Student leadership contributes to respect, autonomy and self-regulation:

They know that on two days we work in the corners and they have to do everything. In the end, we all achieve the same goals. There is no set time for activities, students work at their own pace (LC, S, TI)

In the last three years, the families have been involved in some classroom activities, such as peer tutoring at home:

Yes, I do it with my mum or my dad at home. When it is my turn to be the tutor, I practice being the tutee and we read it like... 1st reading, 2nd reading, 3rd reading and I ask the questions and the person that's with me acts as the tutor and corrects my mistakes. (PT,IS)

On Thursday afternoons, parents chose and ran workshops for all the students. Although these workshops were collaborative, this collaboration was not included in the evaluation of practices, which is still exclusively done by the teachers.

\section{Taking into account the students' voice}

The students referred to the change brought about by their families' participation in the school and valued the opportunity to give their opinions and make proposals for improvement.

What I like, for example, before the parents didn't come to the school so much or do so much for the school. And before, they didn't let the children say what they thought about how to improve, either. (CC, SI,A) 
The students were involved in the group feedback and analysis of the information. They recognised that the PAR helped to analyse data and suggest changes:

I think they listen to our opinions more now than before because we are the ones who can speak up and look at what we can change. For example, in peer tutoring, not always do the same as tutors and change couples every week, the second reading could be done together, not consecutively and we need to make less noise in the classroom (lower voices when everyone's reading in pairs). (CC,SI,A)

The families pointed out that shared values should be included in the school's education project, so as to cover all the advances made over these years and established through a shared vision.

With a view to the next school year, one improvement proposal for the PEC [the school's education project] would be to start putting together the vision of the school to include all the values that we have defined during this school year in the assemblies and event days we've had. (CC, O, F)

The results show that the participatory activities (open days, assemblies for feedback and analysis, observation of classroom practices and the Coordinating Committees) are positively valued, although some difficulties and hurdles are noted such as the times set for family participation and how to ensure students' voices are heard. As participation takes place in different spheres and contexts in the school and involves different groups of people, it has led to more delegation of responsibilities and the sense of a collaborative community, but with this comes the need to learn how to use new intercultural and communicative models and create spaces to share information and take group decisions. 
This perception of institutional change was evidenced in the participants' opinions about the ability to reach decisions through consensus, learning a culture of participation, and embodying these changes in documents that define the school's identity as a democratic and inclusive community.

\section{Discussion and conclusions}

Undertaking participatory action-reflection processes provided spaces and times for reflection, debate and sharing about inclusive practices and intercultural relationships among the different groups in the educational community. This process has helped to generate a series of attitudes, values and beliefs that influence not only relationship models, ways of association and organisation in the school, but the meaning and purpose of the school itself (Kapoor and Jordan, 2009).

Yet this is not a gradual linear process; it exposes the tensions surrounding the political vision of the transformation process. Democratic participation comes with ideological connotations that create tension between the families, the teaching staff and the management team. This tension is a normal part of both the educational process towards inclusion and PAR, and as such it must be recognised and managed appropriately so the shift towards democratisation does not turn into an acritical process that reproduces inequalities. Participation and leadership in inclusive and intercultural schools need to address the new meanings of diversity and build a more democratic and collaborative learning community (Oswald and Engelbrecht 2013).

Brydon-Miller and Maguire caution that 'the narrowing of the meaning of democracy under neo-liberalism, has moved from preparing teachers to advocate for democracy and equity to preparing technicians to implement measures to increase test scores' $(2009,85)$. Kemmis $(2006,469)$ considers that action research should be a tool 
to explore the work of teachers, students and schools as a community in a more openminded way that understands the process as one part of a whole system. Therefore, the critical examination intrinsic to PAR in this democratisation of the systems of power and privilege highlights the importance of fostering shared leadership, since as BrydonMiller and Maguire (2009) point out, PAR facilitates opportunities to generate more inclusive policies, intercultural communication and more empowering practices through bottom-up educational reform. This critical analysis of distributed leadership prevents a narrow conception of organisation where democratic agency is a delegation of power within an unchanged positional hierarchy rather than a right to exercise democratic participation (Gunter, Hall and Bragg 2013).

Thus, we can confirm the fundamental role the management team plays in this new conception of school leadership and the resistance in the system to taking on more distributive and horizontal decision-making and power structures. The inertia in school decision-making bodies tends to mean power is personified in the figure of the headteacher, despite his or her intentions to distribute and delegate responsibilities among families and students. The real challenge for formal leaders is organisational redesign to create opportunities for others so that school change is based on mutual trust (Harris 2013). As Harris contends, 'this does not mean that everyone is a leader, or should be, but it opens up the possibility for a more democratic and collective form of leadership' (2003, 317).

PAR strategies (open days, PSD techniques, shared analysis of didactic practices and the Coordinating Committee) enabled discussion and critical thinking about school and family timetables, issues that students and parents can decide on, or how participative committees really are for vulnerable voices. 
Dworski-Riggs and Langhout (2010) conclude that power differences could be considered an opportunity to refine the research methods and challenge power structures instead of being seen as a setback to participation for inclusion. The key limitations to democratic participation should therefore be identified in order to enable decision making by school stakeholders. Dworski-Riggs and Langhout (2010) suggest that school policies on supervision and permission, time, and social norms (structured hierarchically) may present barriers to democratic participation. From a socially critical approach, these policies are related to the economic and political interests that configure and operate power relationships. Consequently, changing leadership in school is more about structural changes focused on rights and opportunities rather than how tasks are performed (Gunter, Hall and Bragg 2013).

The range of issues families and students can decide on continues to be controversial and generates tension in the school democratisation process. PAR strategies were used in an attempt to create participatory spaces and tools (open days, mirror technique, assemblies) that ensure equal participation. Although a wide range of voices was heard in the meetings, the decision-making process is not perceived to be an equal one. Families and students are aware of this limitation, which shows that the locus of power remains with the headteacher and leadership is not yet democratically distributed (Woods 2017).

On this point, Dworski-Riggs and Langhout $(2010,226)$ argue that 'in communities or organizations where shared decision making is not the norm, PAR should be seen as an intervention that must challenge boundaries to participation and thereby create conditions that foster empowerment and initiate second order change (it alters relationships and is more systemic)'. Indeed, a transformative approach to school culture and leadership should focus on the way in which inequities affect the outcomes 
in educational organisations in order to encourage leaders to ensure more equitable learning environments for all children (Shields 2010).

For this reason, a key factor related to shared leadership in the democratisation process was the development of a collaborative culture in the school as a framework for effective practice. Instead of a philosophy of dependence, collaborative leadership is grounded in the co-development philosophy that fosters human agency and relational freedom from the idea of social justice and participation (Woods and Roberts 2018).

The idea of working together, collaborating in social change, is based on a distributed leadership, but also needs a common, shared goal and the guarantee that all members have the right to be included. As Blackmore (2009) points out, leadership for social justice has to recognise not only individual differences but also structural and cultural inequalities by being more sensitive to issues of class, gender, race and religion.

The collaborative ethos of PAR can also change university-based teacher education. The relationship established between researchers and participants in the research aims to be more horizontal and dialogue-based, and one in which participants control and are at the forefront of the process and results of a participatory research experience. This approach therefore involves constant negotiation of objectives and strategies to encourage more participatory and collaborative inquiry processes in school culture (Maguire and Horwitz 2005; 2008).

Although the change in the relationship between families, teaching staff and the management team, on the one hand, and the research team (as external consultants) and the school, on the other, is gradually moving towards a collaborative culture, the involvement of students as an equally valid group in the educational community is still the most vulnerable and difficult to articulate (Jadue Roa and Whitebread 2012). The 
PAR's participatory strategies provided an opportunity to empower students by recognising their voice and their agency in the inquiry process (Mitra and McCornick 2017). The students' participation in the PAR helped them to access and understand the information, involved them in the group feedback and analysis of this information, and encouraged their participation in decision making together with their families and local agents. This became a crucial part in the democratisation process in that 'research takes diverse shapes and forms to assure children's participation and a reliable process of listening to their "voices", jointly constructing meaning with them and within their environments.' (Jadue Roa 2017, 332). This is the shift that students' voices should make towards a leadership, school culture and organisation that foster respectful relationships and identities within a learner-centred policy (Smyth, 2006).

Finally, it is vital that schools have the autonomy to develop their democratisation and improvement processes. Ainscow, Dyson, Goldrick and West (2016) conclude that national policies should foster greater flexibility at the local level, so that practitioners have the space to analyse their particular circumstances and determine priorities accordingly.

In light of the above, the research approach must be coherent with inclusive and intercultural principles, which can lead to dilemmas and contradictions that need to be brought out into the open. According to Stack and McDonald (2014), inclusive research as a branch of action research shares with PAR, community-based participatory research and emancipatory research, the principles of egalitarian reciprocal corporation, empowerment of its members, and a balance between research and community action centred on change in individuals and in the system. These principles are essential to explore school democratisation processes such as those analysed in this study. 
Acknowledgements

The authors are grateful to the entire school community for their goodwill and commitment. Our thanks are also due to Mary Savage for her translation.

Funding

This work was supported by Spanish Ministry of Economy and Competitiveness: "The Included School: Planning and Implementing Curricular Educational Practices Linked to the Territory." [EDU2013-46491-R] and "Making the school part of the community: Planning and implementation of educational curriculum practices linked to the territory"[EDU2015-68004$\mathrm{R}]$.

References

Aguirre, A., A. Sales, and P. Escobedo. 2014. "Construyendo la escuela intercultural inclusiva desde el diagnóstico social participativo”. Paper presented at XI International Conference University and Inclusive Education. Universitat Jaume I, Castellón, April, 8-10. Quaderns digitals. NET. http://www.quadernsdigitals.net/index.php?accionMenu=hemeroteca.VisualizaA $\underline{\text { rticuloIU.visualiza\&articulo_id=11333\&PHPSESSID=e8d226141e1c280da893 }}$

Aguirre, A. A. Benet, A. Sales, O. Moliner, and J.A. Traver. 2017. Técnicas para la participación democrática. La formación para la convivencia democrática en los procesos de mejora. Castellón: Publicacions Universitat Jaume I. http://dx.doi.org/10.6035/Sapientia132

Ainscow, M. 2005. "Developing inclusive education systems: what are the levers for change?" Journal of Educational Change, 6: 109-124.

Ainscow, M. 2016. Equidad, el gran reto de los sistemas educativos.[Equity, the big challenge of educational systems] In El rumbo de la transformación educativa: temas, retos globales y lecciones sobre la reforma esctructural [Leading Educational Change: global issues, challenges, and lessons on whole-system reform]. Coordinated by H. J. Malone, 101-106, México: Fondo de Cultura Económica.

Ainscow, M., A. Dyson, S. Goldrick, and M. West. 2012. "Making schools effective for all: rethinking the task". School Leadership \& Management 32 (3): 197-213. 
Ainscow, M.; A. Dyson, S. Goldrick, and M. West. 2016. "Using collaborative inquiry to foster equity within school systems: opportunities and barriers School". Effectiveness and School Improvement 27 (1): 7-23.

Alberich, T., L. Arnanz, M. Basagoiti, R. Belmonte, P. Bru, C. Espinar, et al. 2009. Manual de metodologías participativas. Madrid: Red cimas. http://www.redcimas.org/wordpress/wpcontent/uploads/2012/09/manual_2010.pdf

Alberich, T. 2008. IAP, redes y mapas sociales: desde la investigación a la intervención. Portularia viii (1): 131-151. http://revistaredes.rediris.es/webredes/portularia/08.Tomas_Alberich_Nistal.pdf

Ander-Egg, E. 2012. Repensando la investigación-acción-participativa. [Rethinking Participatory Action Research] Buenos Aires: Lumen-Humanitas.

Armstrong, F. and M. Moore. 2004. Action research for inclusive education: Changing places, changing practices, changing minds. London: Routledge Falmer.

Armstrong, F., D. Armstrong, and L. Barton. 2000. Inclusive education: Policy, contexts and comparative perspectives. London: David Fulton.

Baum, F., C. MacDougall, and D. Smith. 2006. "Participatory action research". Journal of Epidemiology and Community Health 60 (10): 854-857.

Blackmore, J. 2009. “Leadership for Social Justice: A transnational Dialogue”. Journal of Research on Leadership Education 4 (1): 1-10. https://files.eric.ed.gov/fulltext/EJ875405.pdf

Bourn, D. 2015. “Teachers as agents of social change”. International Journal of Development Education and Global Learning 7 (3): 63-77. DOI: 10.18546/IJDEGL.07.3.05

Brydon-Miller, M. and P. Maguire. 2009. "Participatory action research: contributions to the development of practitioner inquiry in education". Educational Action Research 17 (1): 79-93. https://doi.org/10.1080/09650790802667469

Castro, P., M. Alarcón, H. Cavieres, P. Contreras, J. Inzunza, J. Marimbio, E. Palma, et al. 2007. "El diagnóstico participativo como herramienta metodológica en la asesoría educativa".[Participatory diagnosis as a methodological tool in educational counceling] REICE. Revista Iberoamericana sobre Calidad, 
Eficacia y Cambio en Educación 5 (5e): 163-171.

https://revistas.uam.es/index.php/reice/article/view/5484/5922

Cisterna, F. 2005. “Categorización y triangulación como procesos de validación del conocimiento en investigación cualitativa".[Categorization and triangulation as validation process of knowledge in qualitative research] Theoria 14 (1): 61-71. http://www.redalyc.org/articulo.oa

Coulby, D. 2011. "Intercultural education: The Theory Deficit and the World Crisis". In Intercultural and Multicultural Education. Enhancing Global Interconnectedness edited by C. A. Grant \& A. Portera, 98-109. New York: Routledge.

Darling-Hammond, L. 2006. "Securing the right to learn: Policy and practice for powerful teaching and learning”. Educational Researcher 35 (7):13-24. https://doi.org/10.3102\%2F0013189X035007013

Deltoro, E. 2004. Cómo hacer proyectos de animación para trabajar con niños y jóvenes.[How to develop sociocultural projects for kids and youngsters] Certeza: Zaragoza.

Dickson, G. and K.Green. 2014. "Participatory Action Research: Lessons Learned from Aboriginal Grandmothers". Health Care for Women International 22 (5):471482. https://doi.org/10.1080/073993301317094290

Dworski-Riggs, D. and R.D. Langhout. 2010. "Elucidating the Power in Empowerment and the Participation in Participatory Action Research: A Story About Research Team and Elementary School Change". Am J Community Psychol 45: 215-230. DOI: https://dx.doi.org/10.1007\%2Fs10464-010-9306-0

Echeíta, G., C. Simón, M. Sandoval, and H. Monarca. 2013. Cómo fomentar las redes naturales de apoyo en el marco de una escuela inclusiva: propuestas prácticas.[How to promote natural support networks in inclusive school: practical proposals]. Sevilla: Editorial MAD.

Elliott, J. 1991. Action Research for educational change. Buckingham: Open University Press.

Elo, S. and H. Kyngäs. 2008. "The qualitative content analysis process". Journal of Advanced Nursing 62: 107-115.doi: 10.111/j1365-2648.2007.04569.x 
Escudero, J. 2004. Análisis de la realidad local. Técnicas y métodos de investigación desde la Animación Sociocultural. [Analysis of the local reality. Research techniques and methods from Leisure education] Madrid: Narcea.

Fullan, M.; J. Quinn, and J. McEachen. 2018. Deep Learning. Engage the World. Change the World. California: Corwin.

Guba, E.G. and Y. S. Lincoln. 1985. Naturalistic Inquiry, Beverly Hills, Sage.

Gunter, H.; D. Hall, and J. Bragg. 2013. Distributed Leadeship: A study in knowledge production. Educational Management Administration \& Leadership 4 (5): 555580. https://doi.org/10.1177/1741143213488586

Hargreaves, A. and D. Fink. 2006. Sustainable leadership. San Francisco: John Wiley Bass.

Harris, A. 2003. “Teacher Leadership as Distributed Leadership: heresy, fantasy or possibility?" School Leadership \& Management 23 (3): 313-324. https://doi.org/10.1080/1363243032000112801

Harris, A. 2003. “Distributed Leadership: Friend or Foe?” Educational Management \& Leadership 41 (5): 545-554.

Holliday, A. 1999. "Small cultures”. Applied Linguistics 20 (2): 237-264.

Jadue Roa, D. S. 2017. "Ethical issues in listening to young children in visual participatory research”. International Journal of Inclusive Education 21 (3): 332-345. http://dx.doi.org/10.1080/13603116.2016.1260829

Jadue Roa, D. S. and D. Whitebread. 2012. "Young Children's Experiences Through Transition between Kindergarten and First Grade in Chile and Its Relation with their Developing Learning Agency”. Educational \& Child Psychology 29 (1): $29-43$. https://www.academia.edu/19620087/Young_children_s_experiences_through_t ransition_between_kindergarten_and_first_grade_in_Chile_and_its_relationship _with_their_Developing_Sense_of_Learning_Agency

Kapoor, D. and S. Jordan. 2009. Education, Participatory Action Research and Social Change. International Perspectives. New York: Palgrave MacMillan. 
Kemmis, S. 2006. "Participatory action research and the public sphere". Educational Action Research 14 (4): 459-476. http://dx.doi.org/10.1080/09650790600975593

Kemmis, S., R. McTaggart, and R. Nixon. 2014. The Action Research Planner. Doing Critical Participatory Action Research. Singapore: Springer.

Kincheloe, J. L. and Sh. R. Steinberg. 1997. Changing multiculturalism. Buckingham: Open University Press.

Le Grange, L. 2009. "Participation and Participatory Action Research (PAR) in Environmental Education Processes: For What Are People Empowered?" Australian Journal of Environmental Education 25: 3-14. https://doi.org/10.1017/S0814062600000367

Lozano, M., J.A. Traver, and A. Sales. 2016. "La escuela en el barrio. Cartografiando las necesidades de cambio socioeducativo". Aularia. Revista Digital de Comunicación, 5 (2): 13-20. file:///C:/Users/Auxi/Downloads/DialnetLaEscuelaEnElBarrioCartografiandoLasNecesidadesDeC-5423140\%20(2).pdf

Maguire, P. and J. Horwitz. 2005. "Nurturing transformative teacher action research in a teacher education program: Possibilities and tensions". Paper presented at the AERA Annual Meeting, Montreal, April 11.

Maguire, P. and J. Horwitz. 2008. "Participatory action research by teachers and students: Implications of two alternative high school greenhouse projects and a university teacher AR project - New York City and rural New Mexico”. Paper presented at the AERA Annual Meeting, in New York City, April 9.

Mitra, D. and P. McCormick. 2017. "Ethical dilemmas of youth participatory action research in a democratic setting". International Journal of Inclusive Education 21 (3): 248-258. https://doi.org/10.1080/13603116.2016.1260835

Muijs, D., M. Ainscow, Ch. Chapman, and M. West. 2011. Collaboration and Networking in Education. Singapore: Springer.

Reason, P. and H. Bradbury (Eds) 2008. Action Research Participative Inquiry and Practice (Second Edition). London: Sage Publications

Rodríguez, C., O. Lorenzo, O., and L. Herrera. 2005. “Teoría y práctica del análisis de datos cualitativos. Proceso general y criterios de calidad”.[Theory and Practice 
of Qualitative Data Analysis. General Process and Quality Criteria] Revista Internacional de Ciencias Sociales y Humanidades, SOCIOTAM XV (2): 133154. http://www.redalyc.org/pdf/654/65415209.pdf

Sales, A., J.A. Traver, and R. García. 2011. "Action research as a school-based strategy in intercultural professional development for teachers". Teaching and Teacher Education, 27 (5): 911-919. https://doi.org/10.1016/j.tate.2011.03.002

Shields, C.M. 2010. “Transformative Leadership: Working for Equity in Diverse Contexts". Educational Administration Quarterly 46 (4): 558-589.

Sleeter, Ch. 2007. "Vice President's address: Equity, democracy, and neoliberal assaults on teacher education". Paper presented at the American Educational Research Association Annual Conference, Chicago, April 11.

Smyth, J. 2006. "'When students have power': Student engagement, student voice, and the possibilities for school reform around 'dropping out' of school". International Journal of Leadership in Education 9 (4):285-298. https://doi.org/10.1080/13603120600894232

Stack, E. and K. McDonald. 2014. "Nothing about us without us: Does action research in Developmental disabilities research measure up?" Journal of Policy and practice in Intellectual Disabilities 11 (2):83-91. https://doi.org/10.1111/jppi.12074

Stake, R. E. (1995). The Art of Case Study. Thousand Oaks, CA: Sage.

Susinos, T. and C. Rodríguez-Hoyos. 2011. "La educación inclusiva hoy. Reconocer al otro y crear comunidad desde el diálogo y la participación”. [Inclusive Education nowadays. Acknowledging the Other and creating a community through dialogue and participation] Revista Interuniversitaria de Formación del Profesorado 25 (1): 15-30. file:///C:/Users/Auxi/Downloads/DialnetLaEducacionInclusivaHoy-3426210\%20(2).pdf

Villasante, T.R. 1998. Cuatro redes para mejor vivir.[Four networks to live better] Buenos Aires: Lumen.

Williams, B., and M. Brydon-Miller. 2004. "Changing directions: Participatory action research, agency, and representation". In Ethnography unbound: From theory 
shock to critical praxis, edited by S.G. Brown and S. Dobrin, 241-57. Albany, NY: State University of New York Press.

Woods, P. 2017. "Researching Holistic Democracy in Schools. A Respons to 'Examination of the New Tech Model as a holistic democracy", Democracy \& Education 25 (1) https://democracyeducationjournal.org/home/vol25/iss1/7

Woods, P., and A. Roberts. 2018. "Collaborative school leadership in a global society: A critical perspective". Educacional Management Administration \& Leadership https://doi.org/10.1177\%2F1741143218759088 